\title{
Why is so important to work with bathymetry and side scan sonar and/or backscatter acoustic data simultaneously?
}

\author{
Luiz Antonio Pereira de Souza, Institute for Technological Research - IPT
}

Copyright 2021, SBGf - Sociedade Brasileira de Geofísica

This paper was prepared for presentation during the $17^{\text {th }}$ International Congress of the Brazilian Geophysical Society held in Rio de Janeiro, Brazil, 16-19 August 2021.

Contents of this paper were reviewed by the Technical Committee of the $17^{\text {th }}$ International Congress of the Brazilian Geophysical Society and do not necessarily represent any position of the SBGf, its officers or members. Electronic reproduction or storage of any part of this paper for commercial purposes without the written consent of the Brazilian Geophysical Society is prohibited.

\begin{abstract}
It is remarkable interesting the possibility to use multi acoustic approach for shallow water geophysical investigation projects. Sometimes one seismic source is not enough for getting the best solution for project demands. Even in cases when the target is only the morphology of the bottom surface, the possibility of watch the bottom from the perspective of bathymetry, side scan sonar and/or backscatter acoustic data together is always welcome. The technology is quickly running towards this direction, allowing the researchers to combine several acoustic tools in a simultaneous data field acquisition procedure. This article discusses the approach of morphological investigation of bottom surfaces in shallow water investigation projects.
\end{abstract}

\section{Introduction}

It is well known that acoustic tools are the best technology for underwater investigation. The main reason for that is related to the facilities of sound propagation in water. The technology available today makes easy to deal with several seismic sources simultaneously. In case of underwater bottom surfaces morphological investigation, the possibility of joining bathymetry, side scan sonar and/or backscatter data offer a solid contribution for developing the best geological and geotechnical model of the research area. The same approach can be applied for sub bottom profilers, as different SBP frequencies produce distinct data under the resolution and penetration point of view. This article will highlight the importance of multiple acoustic approach for bottom surface investigation only, so, I'm going to discuss multifrequency surveys projects that demand detailed data about bottom morphology and sedimentary characterization.

\section{Method}

This article will not present the principles of the acoustics, as they are well done in many articles and books (Brisson et al. 2014a,b, Felix et al. 2017, Souza \& Gandolfo 2012, Gallea et al. 1989, Souza et al. 2013, Souza et al. 2007, Souza et al. 2003, Atherton 2011, Lurton 2002, Mazel 1985 and Fish \& Carr 1990).

The target here is to show some examples where multiple acoustic approach on underwater bottom investigation led researchers towards the best solution for some specific needs. From this point of view, data from single beam, multibeam, side scan sonar and backscatter systems will be presented and briefly analyzed.

\section{Examples}

Single beam bathymetric surveys are still a particularly important tool for underwater morphology investigation. If profiles are done as close as possible, the final product will be a detailed topographic map. Single beam surveys have special utility on shallow water investigation where multibeam surveys cannot run, or when the relationship cost/benefits is not reasonable for the project. However, we have to keep in mind that, even when profiles are located very close each other, we will never know what we have in between. We should also consider that sometimes we see bottom anomalies on single beam profiles that we are not able to conclude about their nature based only on bathymetric profile observation. Figure 1 shows an example where only a side scan sonar data can offer an image that makes possible to conclude about the nature of the topographic anomaly, we saw on single beam profile. Without a side scan sonar image, it was not possible to be sure about that.

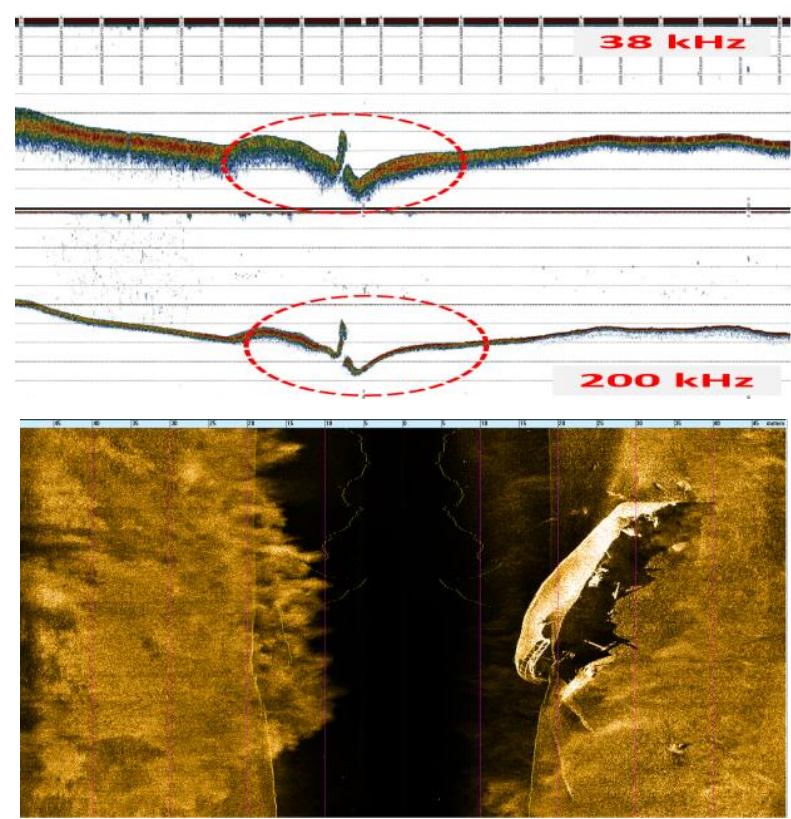

Figure 1: top: double frequency single beam $(38 \& 200 \mathrm{kHz})$ profile showing a topographic anomaly; below, a side scan sonar image $(500 \mathrm{kHz})$ showing the target that caused the topographic anomaly. Santos channel harbor area, São Paulo. IPT data from a Kongsberg EA400 Single beam system and a Klein 3000 Side Scan Sonar.

Sometimes, even a multibeam bathymetric system cannot offer the best product for some targets. If you are studying 
marine habitats and, the bottom topography of the research area is not so conspicuous, a side scan sonar, or a backscatter image, could offer an extremely useful information to help the interpreter to conclude about the nature of the bottom surface, as shown on examples illustrated on Figure 2 and Figure 3.
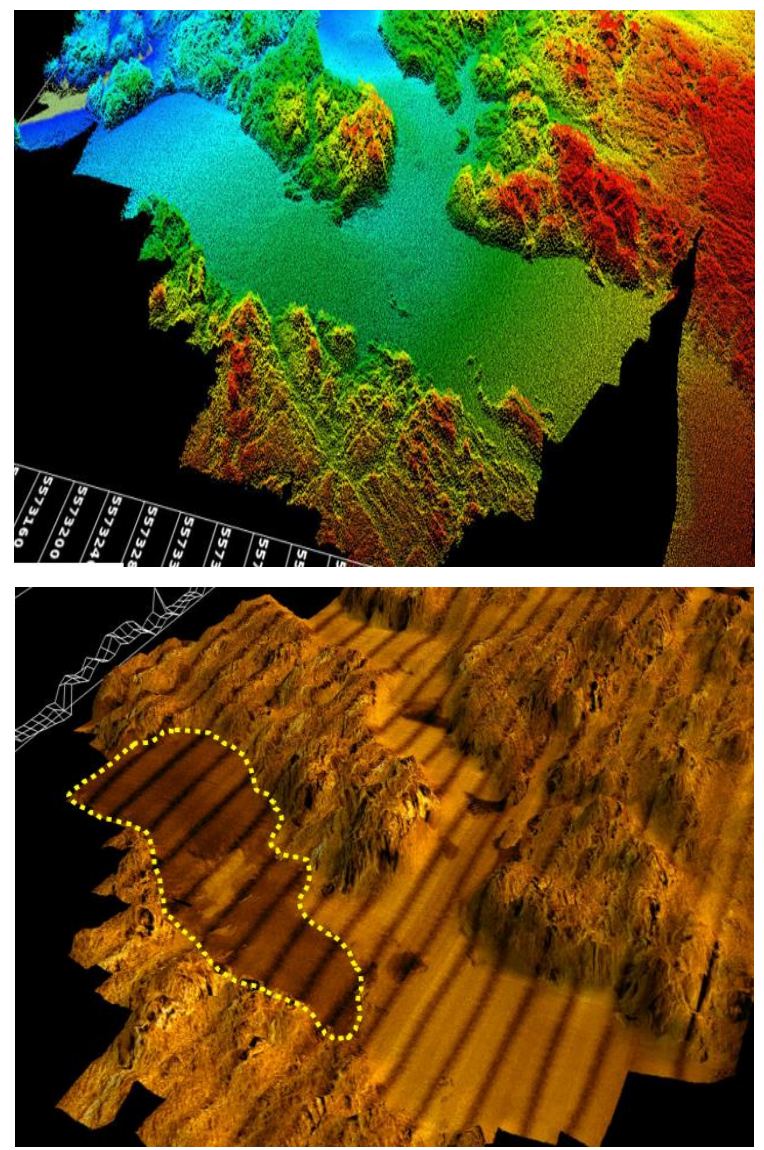

Figure 02: top: image from a multibeam system (Edgetech 6205 Multifase system) showing the detailed bottom topography but not the bottom texture; below: a side scan sonar image in 3D, in the same area, showing different bottom textures (highlighted in yellow) related to a distinct sedimentary material, which is not visible on the bathymetric map (Souza \& Brisson 2016)

\section{Conclusions}

The examples presented above allow us to conclude that at least a couple of high-resolution acoustic tools are mandatory when surface bottom investigation is the main target on an investigation project. From basic bathymetry surveys for habitat mapping, geology and search operation, targets can only be reached with plenty of results if a combined high resolution acoustic tools are applied. For high resolution acoustic tools, we mean side scan sonar systems operating with frequencies over 300 $\mathrm{kHz}$, a single beam dual frequency system and a multibeam (or interferometric or multifase) systems which deals with frequencies from $200 \mathrm{kHz}$. Figure 04 shows a triple product coming from a bathymetric, backscatter and side scan sonar survey.
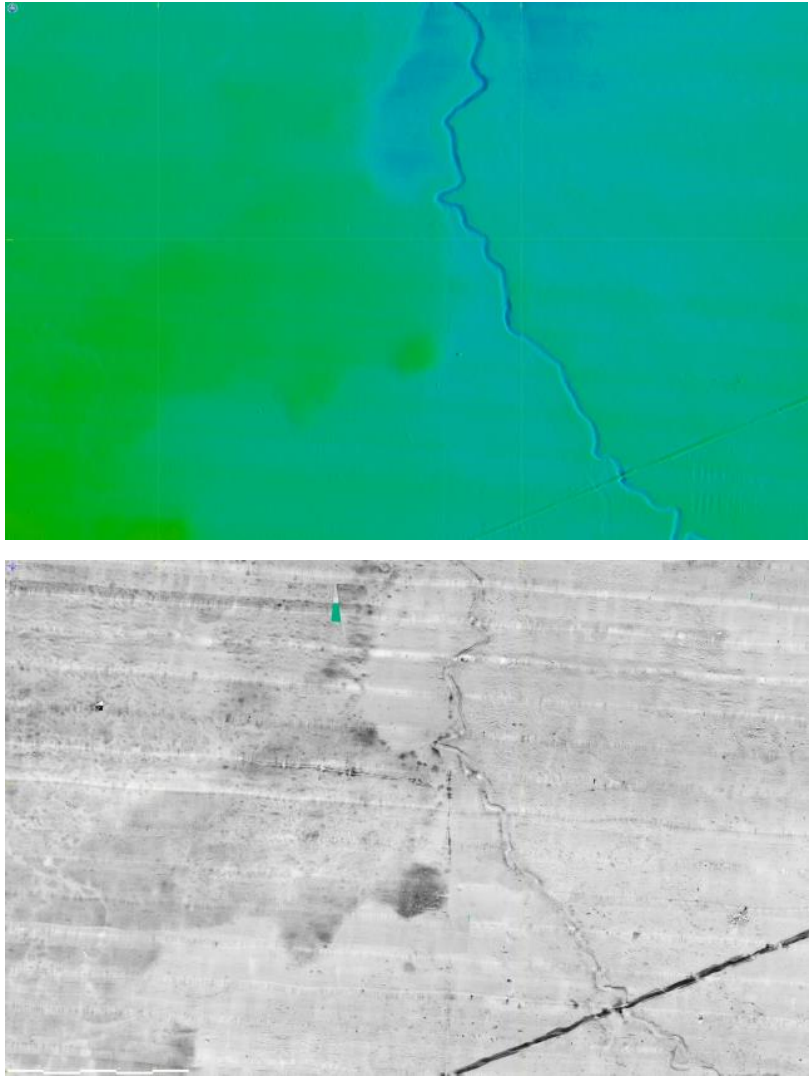

Figure 3: top: image from a multibeam system (Edgetech 6205 Multifase system data) showing a smooth bottom topography (not so conspicuous bottom morphology could be observed); below: a side scan image where it is allowed to recognize the contrasts between at least two distinct bottom textures (geology), which we can see so clearly on the bathymetric image.
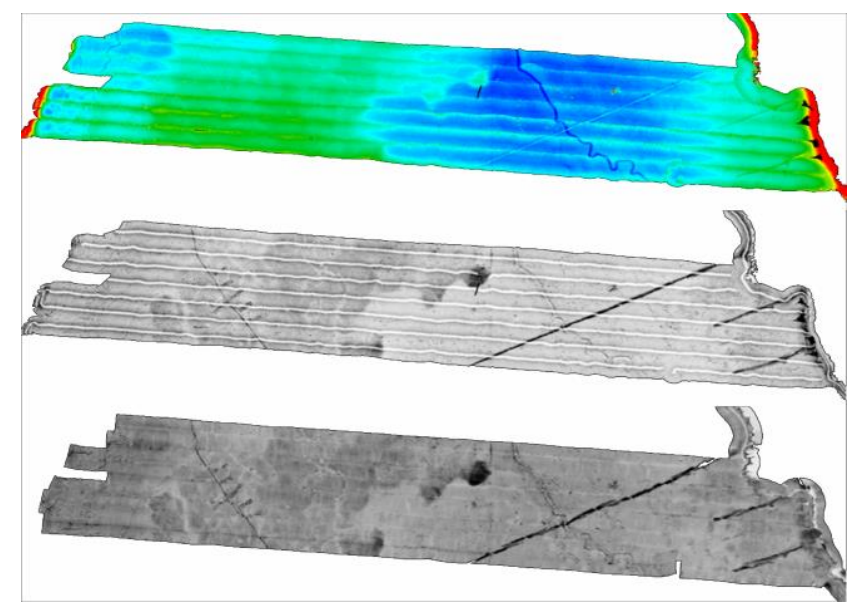

Figure 4: a combined product (bathymetry, side scan sonar image and backscatter images) for a lake close to São Paulo city, showing distinct bottom features: top: the bathymetric map shows the surface morphology; middle (side scan sonar) and bottom (backscatter) images show distinct textures of the bottom surface of the lake, features that are direct correlated to the sedimentary characteristics of the lake (Souza \& Gandolfo, 2021)

\section{References}


ATHERTON, M. K. Echoes and Images. In: The Encyclopedia of Side-Scan and Scanning Sonar Operations. Vancouver: Oysterlnk Publications, 2011. $456 \mathrm{p}$.

BRISSON, L.N. WOLFE, D. AND PSM M.S. "Interferometric swath bathymetry for large scale shallow water hydrographic surveys", proceedings of Canadian Hydrographic Conference, 2014. 2014b.

BRISSON, L.N., RATON, B., WOLFE, D. "Performance analysis of the EdgeTech 6205 swath bathymetric sonar", in <http://www.edgetech.com/wp-content/uploads/2013/09/ Performance-Analysis-of-the-EdgeTech-6205-Swath-

Bathymetric-Sonar.pdf>. 2014a

Felix C; AYRES NETO, A.; SOUZA, L. A. P. Scouting for Energy Cable Route For an Island off Rio Multifrequency, HighResolution Seismic Survey for Cable Planning. SEA TECHNOLOGY. , v.58, p.14-16, 2017

FISH, J. P.; CARR, H. A. A guide to the generation and interpretation of side scan sonar data. 2. ed. Orleans: Lower Cape Publishing, 1990. $188 \mathrm{p}$.

GALLEA, C. G.; SOUZA, L. A. P.; BIANCO, R. A geofísica marinha de alta resolução: características e aplicações In: o Congresso Internacional da Sociedade Brasileira de Geofísica, 1989, Rio de Janeiro. o Congresso Internacional da Sociedade Brasileira de Geofísica, 1989. v.1. p.176

LURTON, X. An introduction to underwater acoustics: principles and applications. Chichester, UK: Praxis Publishing, 2002.

MAZEL C. Side scan sonar training manual. Salem, NH: Klein Associates, Inc., 1985.

SOUZA, L. A. P.; BIANCO, R.; CUNHA, A. G. N. Sonar de varredura lateral: um exemplo de aplicação no estudo de áreas de implantação de dutos submarinos In: 80 . congresso internacional da sociedade brasileira de geofísica, 2003, rio de janeiro. Boletim de resumos expandidos do $8^{\circ}$. Congresso Internacional da Sociedade Brasileira de Geofísica. Rio de Janeiro: Sociedade Brasileira de Geofísica, 2003.

SOUZA, L. A. P.; BIANCO, R.; TESSLER, M. G.; GANDOLFO, O. C. B. Investigações Geofísicas em áreas submersas: qual o melhor método? In: X International Congress of the Brazilian Geophysical Society, 2007, Rio de Janeiro. Boletim de resumos expandidos, 2007. v.1.

Brisson, L. N.; Souza, L. A. P. The echoes of Plymouth sound. In: CONGRESSO BRASILEIRO DE GEOLOGIA, 48, 2016, Porto Alegre - RS. Anais... São Paulo - SP: Sociedade Brasileira de Geologia, 2016. <http://sbgeo.org.br>. Acesso: 30 de outubro 2016. ISBN: 978-85-99198-13-1.

SOUZA, L. A. P.; GANDOLFO, O. C. B. Métodos geofísicos em geotecnia e geologia ambiental. Revista Brasileira de Geologia de Engenharia e Ambiental (RBGEA), v.2, p.9 - 27, 2012.

SOUZA, L. A. P.; SILVA, M.; OLA, K. Why multi-frequency approach on shallow water seismic investigation? In: INTERNATIONAL CONGRESS OF THE BRAZILIAN GEOPHYSICAL SOCIETY \& EXPOGEF, 13, 2013, Rio de Janeiro.

SOUZA, L. P. P.; GANDOLFO, O. C. B. Geofísica aplicada à geologia de engenharia e meio ambiente: manual de boas práticas. São Paulo: ABGE, 2021.160 p. 